\title{
Studi Perencanaan Sistem Pengolahan Limbah RSUD Dr. Doris Sylvanus Palangka Raya
}

\author{
${ }^{1}$ Yudha Heryanto, ${ }^{2}$ Anwar Muda, ${ }^{2}$ Akhmad Bestari, ${ }^{2}$ Iwan Hermawan \\ ${ }^{1}$ Alumni Program Studi Teknik Sipil Universitas Muhammadiyah Palangkaraya \\ ${ }^{2}$ Dosen Program Studi Teknik Sipil Universitas Muhammadiyah Palangkaraya
}

\begin{abstract}
ABSTRAK
Perencanaan system instalasi air limbah menggunakan metode mathematical equations model for completely mixed activated sludge dengan analitis data terhadap hasil perencanaan meliputi kriteria pembebanan untuk merencanakan pengolahan limbah dan produksi lumpur serta kebutuhan oksigen, sedangkan bak sedimentasi didasarkan konsep pengendapan ideal dengan pengendapan dari partikel mandiri (discrate pertikel) pada bak klorinasi prinsipnya sama dengan proses pengolahan air minum, hanya saja adanya kandungan padatan tersuspensi dan terlarut sehingga dibutuhkan klorin dengan dosis tergantung derajat pembunuhan bakteri yang diinginkan. Hasil penelitian menunjukkan, bahwa hasil dimensi rancangan unit pengolahan air limbah RSUD dr. Doris Sylvanus memberikan suatu data yang menggambarkan kemampuan instalasi pengolahan air limbah (IPAL) yakni untuk bak penampungan $(B=1.5 \mathrm{~m}, \mathrm{~L}=3 \mathrm{~m}, \mathrm{~d}=3 \mathrm{~m})$, bak aerasi $(B=1 \mathrm{~m}, \mathrm{~L}=2 \mathrm{~m}, \mathrm{~d}=2 \mathrm{~m})$. Bak sedimentasi $(\mathrm{B} 1=2 \mathrm{~m}, \mathrm{~L} 1=2 \mathrm{~m}, \mathrm{~d} 1=1.6 \mathrm{~m})$, (B2 $=0.356 \mathrm{~m}, \mathrm{~L} 2=0.35 \mathrm{~m}, \mathrm{~d} 2=2.529 \mathrm{~m})$, dan bak klorinasi $(\mathrm{B}=2 \mathrm{~m}, \mathrm{~L}=1 \mathrm{~m}, \mathrm{~d}=1.6 \mathrm{~m})$. Dengan dimensi tersebut dapat mengolah air limbah sebesar $150 \mathrm{~m}^{3} / \mathrm{hari}$. Sedangkan besarnya produksi lumpur pada bak aerasi $0.899 \mathrm{kh} / \mathrm{hari}$, massa padatan total pada bak sedimentasi $2.4 \mathrm{~kg}$ dan dosis klorin maksimum yang diperlukan sebesar $1.2 \mathrm{mg} / \mathrm{hari}$
\end{abstract}

Kata kunci: pengolahan, limbah, rumah sakit.

\section{PENDAHULUAN}

Sejalan dengan perkembangan penduduk yang semakin pesat, lokasi rumah sakit yang dulunya jauh dari daerah pemukiman penduduk tersebut sekarang umumnya telah berubah dan berada ditengah pemukiman penduduk yang cukup padat, sehingga masalah pencemaran akibat limbah rumah sakit baik limbah cair maupun limbah padat sering menjadi pencetus konflik antara pihak rumah sakit dengan masyarakat yang berada disekitar rumah sakit. Air limbah rumah sakit dapat digolongkan kedalam jenis limbah domestik oleh karena itu pengolahannya dapat dilakukan secara biologis dengan memanfaatkan aktivitas mikroorganisme, salah satu faktor yang mempengaruhi keberhasailan proses pengolahan limbah secara biologis adalah jumlah populasi mikroorganisme yang terdapat didalam limbah dan mampu memecah bahan-bahan organik dengan memanfaatkannya sebagai bahan pertumbuhannya. Atas kondisi tersebut maka pemerintah mewajibkan untuk setiap rumah sakit yang ada agar memperhatikan kondisi limbah yang akan dibuang apakah sudah memenuhi Baku Mutu Limbah Cair yaitu batas kadar jumlah unsur pencemaran dalam limbah. Maka untuk mencapai kondisi tersebut, harus dibuat suatu sistem pengolahan limbah yang tentu saja memperhatikan berbagai kondisi yang ada dalam suatu rumah sakit. 
Secara umum air limbah rumah sakit adalah seluruh buangan cair yang berasal dari hasil proses seluruh kegiatan rumah sakit yang meliputi: limbah domestik cair yakni buangan kamar mandi, dapur, air bekas pencucian pakaian. Limbah cair klinis yakni air limbah yang berasal dari kegiatan klinis rumah sakit. Air limbah rumah sakit yang berasal dari buangan domestik maupun buangan limbah cair klinis umumnya mengandung senyawa polutan organik yang cukup tinggi dan dapat diolah dengan proses pengolahan biologis, sedangkan untuk air limbah rumah sakit yang berasal dari laboratorium biasanya banyak mengandung logam berat yang mana bila air limbah tersebut dialirkan kedalam proses pengolahan biologis, logam berat tersebut dapat mengganggu proses pengolahannya.

Limbah cair adalah air yang tidak bersih dan mengandung berbagai zat yang bersifat membahayakan kehidupan manusia dan lingkungan yang biasanya muncul karena hasil perbuatan manusia itu sendiri atau dengan kata lain limbah adalah sampah cair dari suatu lingkungan masyarakat yang terdiri dari air yang telah digunakan. Pencemaran lingkungan terutama pencemaran terhadap air limbah pada umumnya disebabkan oleh buangan industri, limbah rumah sakit dan limbah rumah tangga yang langsung dibuang ke tanah atau lingkungan tanpa melalui proses penetralisasian yang layak terlebih dahulu. Air limbah rumah sakit adalah limbah yang berasal dari rumah sakit baik yang berasal dari dapur, ruang laboratorium, ruang pasien, ruang operasi, dan lainnya. Rumah sakit sebagai tempat pengumpulan berbagai macam penyakit menular maupun penyakit tidak menular serta rumah sakit itu sendiri selalu dihuni, dikunjungi dan dipergunakan oleh penderita maupun pengunjung sehingga dimungkinkan limbah cair rumah sakit mengandung bakteri patogen maupun non patogen.

Ada dua karakteristik untuk mengetahui kandungan dalam air limbah, yaitu karakteristik fisika dan kimia. Karakteristik fisika yang paling penting dari air limbah adalah kandungan: (a) padatan total yaitu jumlah zat padat yang tertinggal apabila air limbah di uapkan pada suhu $103{ }^{\circ} \mathrm{C}$ hingga $105{ }^{\circ} \mathrm{C}$, (b) padatan larutan yang terdiri dari molekul-molekul organik dan anorganik dan ion-ion yang ada dalam larutan air berdasarkan kemampuannya untuk melayang.yang mana terdiri dari benda-benda terapung, benda-benda mengendap, bendabenda melayang dan benda terlarut.

Karakteristik fisika lainnya adalah: (a) temperatur yang merupakan parameter yang penting karena akan berpengaruh dalam reaksi kimia tersebut, kehidupan biota air dan untuk penggunaan yang sesuai, (b) warna dimana air limbah segar akan berwana abuabu muda, sedangkan air limbah yang sudah septik akan berubah menjadi abu-abu gelap atau hitam tetapi dengan meningkatnya sistem pengumpulan dan lebih banyaknya kondisi anaerob warna air limbah berubah dari abuabu tua dan akhirnya menjadi hitam ketika warna air limbah berubah menjadi hitam biasanya air limbah sudah bersifat septik, (c) bau dimana air limbah yang segar akan berbau sabun atau minyak dan air limbah yang septik akan berbau busuk $\left(\mathrm{H}_{2} \mathrm{~S}\right)$. Air limbah segar mempunyai kekhususan yaitu agak sedikit berbau tidak enak dan (d) kekeruhan yang disebabkan adanya zat padat terlarut, makin banyak lumpur maka kekeruhan main tinggi. Zat padat ini ada yang bisa mengendap dan ada juga yang tidak bisa mengendap (jenis kolloidal), lama waktu yang dibutuhkan oleh zat padat tersebut untuk mengendap tergantung dari berat zat padat itu sendiri (ukuran partikel zat padat dan berat jenisnya) dan keadaan air limbah. Makin besar ukuran partikel dan makin tenang aliran air limbah akan akan makin cepat partikel padat tersebut mengendap sehingga air menjadi jernih.

Kandungan bahan kimia yang ada dalam air limbah dapat mengurangi limbah dalam berbagai cara. Sifat kimia dinyatakan oleh kandungan zat organik dan anorganik.

Pada parameter organik, hal yang diukur adalah Biochemical Oxygen Demand (BOD), Chemical Oxygen Demand (COD) dan Dissolved Oxygen (DO) dengan penjelasan sebagai berikut.

(a) Biochemical Oxygen Demand (BOD) atau kebutuhan biologi akan oksigen 
adalah sejumlah oksigen yang diperlukan bagi mikroorganisme untuk menstabilkan bahan-bahan organik yang bisa terurai dalam kondisi aerobic. Istilah "bisa terurai" dimaksudkan bahwa bahan organik tersebut akan dimanfaatkan oleh bakteri sehingga makanan dan energi diperoleh dari proses oksidasi. Menurut bentuk padatnya bahan organik penyebab nilai BOD dibagi menjadi: (1) bahan padat mengendap rata-tata $30 \%$ (25\% $40 \%)$, (2) bahan padat kolloidal rata-rata $30 \%(25 \%$ - 40\%) dan (3) bahan padat melayang rata-rata $40 \%$ (20\%-50\%). Fungsi hasil tes BOD yang digunakan dalam instalasi pengolahan air limbah adalah untuk menentukan banyaknya jumlah oksigen yang akan dibutuhkan pada penstabilan biologi zat-zat organik yang ada, menentukan ukuran dan fasilitas pengolahan air limbah, menghasilkan effisiensi dari beberapa proses pengolahan dan menentukan pelaksanaan banyaknya air buang yang boleh dikeluarkan.

(b) Chemical Oxygen Demand (COD)

Chemical Oxygen Demand atau kebutuhan kimia akan oksigen banyak digunakan untuk mengukur tingkat pencemaran air kotor rumah tangga dan air buangan industri. Test COD bertujuan mengukur jumlah oksigen yang diperlukan untuk mengoksidasi bahan pencemar menjadi $\mathrm{CO}_{2}$ dan $\mathrm{H}_{2} \mathrm{O}$. Keuntungan utama dari test $\mathrm{COD}$ adalah dapat diperoleh hasilnya yang cepat, sehingga segera dapat dilakukan evaluasi.

(c) Dissolved Oxygen (DO)

Dissolved Oxygen merupakan oksigen terlarut dalam air. Oksigen terlarut ini dibutuhkan untuk pernapasan mikroorganisme aerobik dalam air limbah. Walaupun oksigen larut dalam air, banyaknya oksigen yang ada dalam larutan dapat ditentukan dengan daya larutan udara, tekanan tertentu dari gas dalam atmosfer, temperatur dan kemurnian (kadar garam, Suspended Solid dan lainnya) dari air.

Pada parameter anorganik, hal yang diperhatikan adalah (a) $\mathrm{pH}$ adalah salah satu parameter yang dipergunakan untuk menyatakan sesuatu air dalam keadaan basa atau asam, dengan mengukur konsentrasi ion hidrogen. Pada pengolahan air kotor yang memanfaatkan aktivitas bakteri, $\mathrm{pH}$ harus berada pada batas-batas dimana mikroorganisme itu dapat aktif, (b) alkalinitas, dimana kadar alkali air diukur berdasarkan kemampuannya untuk menetralisir asam. Alkalinitas pada alam terutama disebabkan oleh garam dari asam lemah, walaupun basa lemah ataupun basa kuat juga menjadi penyebab kadar alkali pada air alam, (c) nitrogen yang dalam air limbah terbagi menjadi: organik nitrogen, amonia nitrogen. Air limbah yang segar biasanya mengandung organik nitrogen tinggi dan amonia nitrogen rendah, (d) deterjen (Surfactan) adalah golongan dari molekul organik yang dipergunakan sebagai pengganti sabun untuk pembersih supaya mendapatkan hasil yang lebih baik. Didalam air zat ini menimbulkan buih dan selama proses buih tersebut berada diatas permukaan gelembung udara dan biasanya relatif tetap. Bahan dasar dari deterjen adalah minyak nabati atau minyak bumi dan (e) fosfor yang merupakan elemen penting dalam metabolisme pada mikroorganisme. Fosfor mempercepat pertumbuhan ganggang yang berbahaya.

Selain hal-hal di atas, senyawa organik yang terdapat pada air limbah berupa protein, karbohidrat, lemak, minyak dan gemuk serta deterjen dan tenol. Karbohidrat dan protein biasanya mudah diuraikan secara biologis. Lemak dan minyak serta gemuk lebih stabil dan dapat didekomposisikan dengan perlahan ooleh mikroorganisme. Deterjen adalah golongan molekul organik yang dipergunakan sebagai pengganti sabun untuk pembersih supaya mendapatkan hasil yang lebih baik. Fenol merupakan penyebab timbulnya rasa yang ada dalam air minum, terutama apabila air tersebut dilakukan klorinasi.

Air limbah rumah sakit adalah seluruh buangan cair yang berasal dari hasil proses seluruh kegiatan rumah sakit khususnya pada rumah sakit dr. Doris Sylvanus palangkaraya yang bersumber dari limbah domestic cair yakni buangan kamar mandi, dapur, air bekas pencucian pakaian. Sedangkan air limbah cair 
klinis yang ada di RSUD dr. Doris Sylvanus adalah limbah yang berasal dari kegiatan klinis rumah sakit misalnya air bekas cucian luka, cucian darah, air limbah dari laboratorium. Adapun besarnya jumlah debit pengolahan (Q) air limbah yang ada dirumah sakit dr. Doris Sylvanus adalah 150 m/hari.

Pada penelitian akan dilakukan dengan mengambil lokasi studi berada di RSUD dr. Doris Sylvanus Palangkaraya dimana saat ini merupakan balai pengobatan dengan tipe kelas B yang selalu dituntut untuk meningkatkan fasilitas sarana dan prasarana sebagai penunjang kesejahteraan dan kesehatan masyarakat. Dan salah satu sektor tersebut adalah sistem pengolahan air limbah yang memadai sehingga diharapkan tidak mencemarkan lingkungan sekitarnya

\section{METODE PENELITIAN}

Penelitian dillakukan di RSUD dr. Doris Sylvanus Palangka Raya. Metode penelitian ini mengacu pada diagram alir seperti pada Gambar 1 berikut.

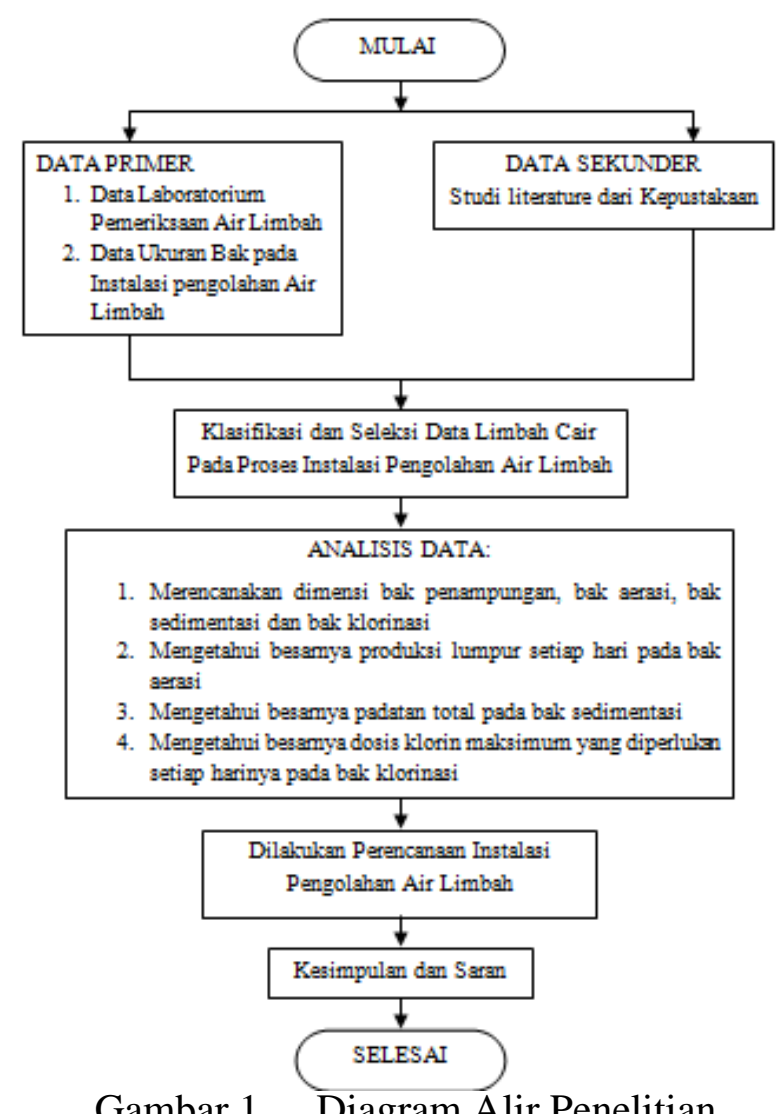

\section{HASIL DAN PEMBAHASAN}

Sumber limbah cair RSUD dr. Doris Sylvanus Palangka Raya berasal dari kegiatan pelayanan rawat jalan (Poliklinik), pelayanan rawat inap dan instalasi gawat darurat. Limbah cair tersebut berasal dari pencucian alat-alat medis yang telah terkontaminasi (baik berupa sisa darah dan lainnya) dan limbah cair domestik yang berasal dari ruang perawatan limbah dari laboratorium yang kebanyakan mengandung bahan-bahan kimia berupa sisa reagen atau sisa sampel dari tubuh manusia. Air limbah rumah sakit yang berasal dari buangan domestik maupun buangan limbah cair klinis umumnya mengandung senyawa polutan organik yang cukup tinggi, dan dapat diolah dengan proses pengolahan secara biologis sedangkan untuk air limbah rumah sakit yang berasal dari laboratorium biasanya banyak mengandung logam berat yang mana bila air limbah tersebut dialirkan kedalam proses pengolahan secara biologis, logam berat tersebut dapat mengganggu proses pengolahannya.

Limbah cair yang berasal dari laundry mengandung campuran deterjen dan limbah kegiatan dapur yang dihasilkan dari pencucian peralatan makan dan peralatan masak, semuanya mengandung zat-zat yang berbahaya bercampur menjadi satu dalam bak penampungan sehingga, apabila limbah cair tersebut tidak cepat diproses dan diolah akan mengakibatkan pencemaran.

Sedangkan komposisi kandungan air limbah berdasarkan hasil pemeriksaan laboratorium dapat dilihat pada Tabel 1.

Tabel 1. Komposisi Kandungan Air Limbah Berdasarkan Hasil Pemeriksaan Laboratorium

\begin{tabular}{cllrrr}
\hline \multirow{2}{*}{ No } & \multicolumn{2}{c}{$\begin{array}{c}\text { Parameter yang } \\
\text { dianalisa }\end{array}$} & Satuan & & \multicolumn{2}{c}{ Lokasi Sampel } & Batas \\
& & & Inlet & Outlet & Maks. \\
\cline { 1 - 1 } A. FISIK & TDS & $\mathrm{mg} / \mathrm{L}$ & 0,560 & 0,192 & 1500 \\
2 & TSS & $\mathrm{mg} / \mathrm{L}$ & 0,27 & 0,20 & 100 \\
3 & Suhu & ${ }^{\circ} \mathrm{C}$ & 28,6 & 28,6 & 35 \\
B. & KIMIAWI & & & & \\
4 & Air Raksa $(\mathrm{Hg})$ & $\mathrm{mg} / \mathrm{L}$ & $\mathrm{ttd}$ & $\mathrm{ttd}$ & 0,001 \\
5 & Krom $(\mathrm{Cr})$ & $\mathrm{mg} / \mathrm{L}$ & $\mathrm{ttd}$ & $\mathrm{ttd}$ & 0,05 \\
6 & pH & & 6,5 & 6,46 & $6-9$ \\
7 & Nitrat $\left(\mathrm{NO}_{2}\right)$ & $\mathrm{mg} / \mathrm{L}$ & 0,05 & 0,03 & 10 \\
8 & Nitrit $\left(\mathrm{NO}_{3}\right)$ & $\mathrm{mg} / \mathrm{L}$ & 0 & 0 & 0,06 \\
9 & BOD & $\mathrm{mg} / \mathrm{L}$ & 10 & 28 & 30 \\
10 & COD & $\mathrm{mg} / \mathrm{L}$ & 8 & 22 & 80 \\
11 & Besi $(\mathrm{Fe})$ & $\mathrm{mg} / \mathrm{L}$ & 0,14 & 0,01 & 5 \\
12 & Zat Organik $\left(\mathrm{KMnO}_{4}\right)$ & $\mathrm{mg} / \mathrm{L}$ & 27,91 & 25,87 & 10 \\
13 & Kalsium $(\mathrm{Ca})$ & $\mathrm{mg} / \mathrm{L}$ & 27,8 & 36,52 & 75 \\
\hline
\end{tabular}




\begin{tabular}{lllrrr}
\hline 14 & Kalium $(\mathrm{K})$ & $\mathrm{mg} / \mathrm{L}$ & 0,012 & 0,010 & - \\
15 & Magnesium $(\mathrm{Mg})$ & $\mathrm{mg} / \mathrm{L}$ & 0,344 & 0,046 & 30 \\
16 & Natrium $(\mathrm{Na})$ & $\mathrm{mg} / \mathrm{L}$ & 0,00 & 0,00 & 0,5 \\
17 & Tembaga $(\mathrm{Cu})$ & $\mathrm{mg} / \mathrm{L}$ & $\mathrm{ttd}$ & $\mathrm{ttd}$ & 1 \\
18 & Seng $(\mathrm{Zn})$ & $\mathrm{mg} / \mathrm{L}$ & 0,002 & 0,001 & 5 \\
19 & Mangan $(\mathrm{Mn})$ & $\mathrm{mg} / \mathrm{L}$ & $\mathrm{ttd}$ & $\mathrm{ttd}$ & 0,5 \\
20 & Timbal $(\mathrm{Pb})$ & $\mathrm{mg} / \mathrm{L}$ & $\mathrm{ttd}$ & $\mathrm{ttd}$ & 0,4 \\
21 & Fosfat $(\mathrm{PO} 4)$ & $\mathrm{mg} / \mathrm{L}$ & 5,619 & 6,097 & 2 \\
22 & Klorida $(\mathrm{Cl})$ & $\mathrm{mg} / \mathrm{L}$ & 3,485 & 2,987 & 600 \\
23 & Deterjen & $\mathrm{mg} / \mathrm{L}$ & 0,21 & 0,11 & 0,50 \\
\hline
\end{tabular}

Sedangkan unit-unit pengolahan air limbah RSUD dr. Doris Sylvanus adalah bak penampungan, bak aerasi, bak sedimentasi (pengendapan) dan bak klorinasi (bak disinfection) dengan skema pengolahan air limbah sebagai berikut.

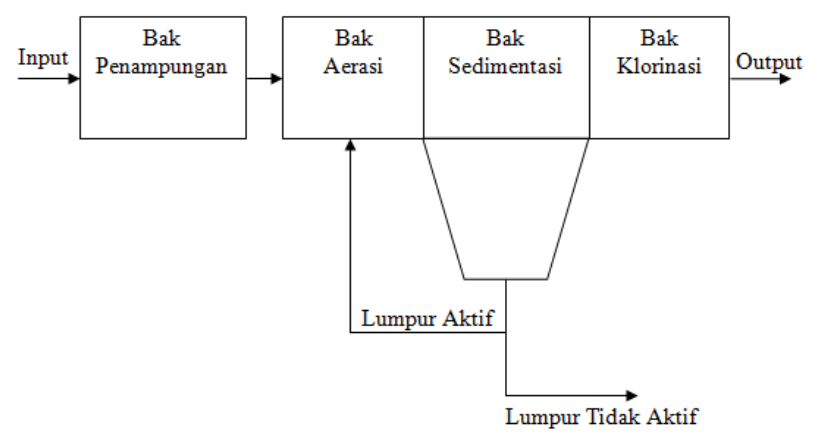

Gambar 2. Skema pengolahan air limbah

\section{KESIMPULAN}

Berdasarkan hasil penelitian maka dapat diberi kesimpulan :

(1) Dari hasil perencanaan unit pengolahan limbah RSUD dr. Doris Sylvanus Palangkara Raya sudah mampu mengolah limbah dengan debit pengolahan (Q) sebesar $150 \mathrm{~m}^{3} / \mathrm{hari}$ dan memenuhi kriteria perencanaan.

(2) Hasil dimensi Bak Penampungan, yaitu B $=2,5 \mathrm{~m}, \mathrm{~L}=5 \mathrm{~m}, \mathrm{~d}=3 \mathrm{~m}$, mampu menampung debit pengolahan air limbah setiap harinya, $\left(\right.$ Vbak $=75 \mathrm{~m}^{3}>$ air $=$ $\left.10,34 \mathrm{~m}^{3}\right)$.

(3) Hasil dimensi Bak Aerasi, yaitu: $\mathrm{B}=1 \mathrm{~m}$, $\mathrm{L}=2 \mathrm{~m}, \mathrm{~d}=2 \mathrm{~m}$, sudah memenuhi kriteria perencanaan dengan model aliran complete mixed dan didapatkan hasil sebagai berikut:

a. Beban volumetrik $=1,050 \mathrm{~kg} \mathrm{BOD} / \mathrm{m}^{3}$ hari.

b. $\mathrm{F} / \mathrm{M}$ rasio $=0,350 \mathrm{~kg} \mathrm{BOD} / \mathrm{kg}$. MLSS . hari.

c. Umur lumpur / waktu tinggal $=13,333$ hari. d. Jumlah kapur yang dibuang setiap hari pada bak aerasi sebesar $0,899 \mathrm{~kg} / \mathrm{hari}$.

e. Jumlah lumpur total berdasarkan SS total rasio MLVSS dengan MLSS = 0,8 adalah $=1,124 \mathrm{~kg} / \mathrm{hari}$.

f. Rasio resirkulasi $=0,429$

(4) Hasil dimensi Bak Sedimentasi, yaitu B1 $=2 \mathrm{~m}, \mathrm{~L} 1=2 \mathrm{~m} \mathrm{~d} 1=1,6 \mathrm{~m}, \mathrm{~B} 2=0,35$ $\mathrm{m}, \mathrm{L} 2=0,35 \mathrm{~m}, \mathrm{~d} 2=2,529 \mathrm{~m}$, sudah memenuhi kriteria perencanaan dan didapatkan hasil sebagai berikut:

a. Waktu detensi (td) $=2$ jam.

b. Over flow rate $(\mathrm{Vo})=36,381 \mathrm{~m}^{3} / \mathrm{m}^{2}$. hari.

c. Massa padatan dalam bak pengendapan $=2,4 \mathrm{~kg}$.

(5) Hasil dimensi Bak Klorinasi/Disinfection yaitu $B=2 \mathrm{~m}, \mathrm{~L} 1=1 \mathrm{~m}, \mathrm{~d}=1,6 \mathrm{~m}$, sedangkan Dosis Klorin yang diperlukan setiap harinya pada bak klorinasi adalah $=1,200 \mathrm{mg} / \mathrm{hari}$.

\section{SARAN}

Berdasarkan kesimpulan penelitian, maka saran yang dapat dipertimbangkan adalah sebagai berikut:

(1) Hal yang terpenting sebelum melakukan pengambilan sampel sebaiknya alat yang digunakan diapstikan bersih sehingga yang diteliti tidak terkontaminasi dengan unsur lain.

(2) Limbah cair sebaiknya jangan terlalu lama ditampung didalam bak penampungan dan harus disesuaikan dengan debit pengolahan karena apabila tidak cepat dialirkan dapat menimbulkan unsur-unsur baru yang lebih berbahaya.

(3) Lumpur yang non aktif sebaiknya segera diangkat dan dibuang supaya dapat mengurangi daya tampung bak sedimentasi. Saat pemberian klorin pastikan dosis yang digunakan tidka melebihi target yang sudah ditentukan supaya menjaga kemungkinan effluen yang dibuang ke lingkungan tidak membahayakan apabila dipergunakan untuk keperluan sehari-hari.

(4) Perlu adanya perencanaan atau pelebaran kembali untuk bak Penampungan agar jumlah air limbah yang masuk lebih banyak. 


\section{DAFTAR PUSTAKA}

Kementerian Lingkungan Hidup, 2009, Perlindungan dan Pengolahan Lingkungan Hidup, Tesis, Program Pascasarjana, UNDIP, Semarang.

Mara, D., Caincros, S., 1994, Pemanfaatan Air Limbah dan Ektra, ITB, Bandung.

RSUD dr. Doris Sylvanus, 2009, Analisis Dampak Lingkungan (ANDAL).

Soeparman, 2002, Pembuangan Tinja dan Limbah Cair, Penerbit Buku Kedokteran, Jakarta.
Sugiarto, 1987, Dasar-dasar Pengolahan Air Limbah, Penerbit Universitas Indonesia, Jakarta.

Said, I. N., 1999, Teknologi Pengolahan air Limbah Rumah Sakit dengan Sistem Biofilter Anerob, Jakarta

Malkhamah, S., 1998, Analisis Mengenai Dampak Lingkungan (AMDAL), Fakultas Teknik Universitas Gadjah Mada, Yogyakarta. 